\title{
Ampulla of Vater Tubulovillous Adenoma
}

National Cancer Institute

\section{Source}

National Cancer Institute. Ampulla of Vater Tubulovillous Adenoma. NCI Thesaurus. Code C27412.

An intestinal-type adenoma arising from the ampulla of Vater. It is characterized by the presence of tubular and villous epithelial structures and it is associated with dysplasia. 